\title{
Self-Efficacy and Employee Commitment in Selected Breweries in South East Nigeria
}

\author{
Chinedu Uzochukwu Onyeizugbe, Obiageli Lilian Orogbu \& Obiageli Blessing \\ Chinwuko \\ Department of Business Administration, Nnamdi Azikiwe University, Awka, Nigeria. \\ E-mail: edu_phd@yahoo.com
}

Received: January 29, 2018

Accepted: February 8, 2018

Published: March 8, 2018

doi:10.5296/bms.v9i1.12790

URL: https://doi.org/10.5296/bms.v9i1.12790

\begin{abstract}
In the present turbulent and unpredictable Nigerian business environment, the lack of self-esteem among employees selected breweries in South East Nigeria seems to make job satisfaction a major problem. The main objective of the study is to identify the extent to which self-efficacy enhances employee commitment in Breweries in South East Nigeria. Specifically, the study seeks to ascertain the extent to which self-esteem relates to job satisfaction of employees in selected brewing firms in South East. The research design adopted by the study was Survey type of design; One hundred and fifty six employees constituted the population which were selected from breweries located in the South East Zone of Nigeria. Questionnaire was used for the purpose of data collection. Pearson Product Moment Correlation was used to test the hypothesis. The results of the Study revealed that there is a significant positive relationship between self-esteem and job satisfaction of employees in the selected brewing firms in South East Geopolitical Zone of Nigeria. The Conclusion drawn was that employees in the selected brewing firms can function properly or remain task oriented, if sense of efficacy is imbibed. The study recommended that employees should ensure that they develop positive self-esteem at work to restore confidence in themselves, devote more time and effort in tackling difficult tasks and feel more relaxed at work.
\end{abstract}

Keywords: Self-efficacy, Employee commitment and social cognitive theory 


\section{Introduction}

The contribution of the Brewing industry to economic development is vast in the sense that they create value for the food chain industry. Brewing industry apart from aiding in meeting fundamental human needs have also played a significant role in deciding nations' economic efficiency. The food and beverage sector remains the largest sector in Nigeria's manufacturing industry. Representing over $30 \%$ of Nigeria’s manufacturing industry and 66\% of total consumer expenditure, Nigeria has an increasing demand for packaged and ready-made food products (www.manufacturingnigeria.com/food). Food and beverages range from food staple such as bread, pastas, and pastries to drinks and wines. In the business competitive environment there is need for food and beverage employees to excel in their role and maintain excellences. Four variables of self-efficacy seem to come into the picture when considering the factors in maintaining excellences. These variables of self-efficacy are self-esteem, positive attitude, self-regulation and self-concept. One of such variables, self-esteem will be considered in this study. Self-esteem which is one of the variables that will be focused on in this paper, and self-efficacy are presumed to be similar variables because employee with highs self-esteem are excepted to be more confident when performing task, thus exposing such an employees to a possible high self-efficacy in a certain task (Uzonwanne \& Uzonwanne, 2014). Self-esteem and self-efficacy seem to be similar because high self-esteem in employees directly influences or provokes confidence when individuals perform tasks leading to high self-efficacy (Uzonwanne and Uzonwanne, 2014). Self-esteem is one's view of his worth or value (Shank, 2012).

The management of Food and Beverage Companies in Nigeria has realized that the success and growth of their companies depends on employee's effectiveness and confidence while performing their task. Self-efficacy of the employees in business organizations like food and beverages company may lead to better work performance, creativity, innovation and problem solving as well as job satisfaction (Popoola \& Zaid, 2015).

However, concept of self-efficacy provides the basis for motivating individuals and personal fulfillment. Self-efficacy also affects thoughts and emotional reactions of an individual (Bandura, 1986). Self-efficacy is synonymous with task-based self-esteem. It can be referred to how individuals judge their abilities to organize and carry out course of action required to achieve pre-determined performance (Lent, Brown \& Hackett, 1996).

Bandura, Father of framework development on self-efficacy stresses on a strong sense of efficacy being an enhancer of human fulfillment and individual's well-being (Bandura, 1994 cited in Ramachaudran, 1998).

Aborisade and Obioha (2009) posit that for employees to generate the required level of satisfaction, human resources must be properly harnessed. In this regard, the progress and success of Breweries depends on the performance of its workers. Owing to these contentions, several studies have heightened the essence of employees' commitment in Brewing firms. Dixit and Bhati (2012) in a study argued that employee commitment brings out sustained productivity in the organization. Brocker (1998) posits that employees that are committed in 
their job with value self-esteem are likely to engage in behavior that is goal-oriented. Self-efficacy in employees will help them to work hard and learn new tasks because they have confidence to succeed in their task.

Employee commitment which is fast becoming an important concept in the Food and Beverage sub-sector is becoming complicated and commitment means the same to all employees. Employee commitment is not static and seems to change over time as situation of employees and their needs change. Organizational commitment is defined as a psychological state that binds the employee to the workplace (Allen and Mayer, 1991 cited in Akhtar, Ghayas and Adil, 2012). However, employee commitment is viewed as having a psychological attachment and loyalty to an organization. High level of commitment in employees can be beneficial to the organization in ways such as continuous flow of improvements, job satisfaction and participation.

In the present turbulent and unpredictable Nigerian business environment, the lack of self-esteem among employees in some brewing firms in South East seems to make job satisfaction a major problem.

The brewing firms in South East Nigeria operate in a dynamic and competitive environment that makes it imperative for these firms to be efficient, be current with nutritional trends, customer tastes and preferences and continuously scanning the business environment to understand challenges and opportunities.

Because of the complex nature of jobs, employees are likely to experience work pressures that affect their job satisfaction and self-esteem with respect to performing prescribed tasks, interacting with team members, and coping with workplace politics, all of which lead to low level of satisfaction. Employees are considerably the valuable assets of the organization. When employees are satisfied with their current job and probably committed to their organization, it increases performance.

However, despite the critical role the brewing industry plays, the issue of self-efficacy of employees in these firms and how it affects their commitment has reduced some of their efficiency. The lack of self-esteem has made job satisfaction unavoidable in these firms. Most of the employees in the studied breweries seem to lack self-esteem which enhances self-efficacy. These employees seem not to have a perceived sense of self-worth or respect for oneself. As a result of this, they are being viewed as not been satisfied with their job and this limits their level of commitment and productivity in the firm. Employees in these breweries seem to clamour for self-confidence and learning programmes such as evaluation on the progress of goals which enhances self-efficacy, sustains motivation, improves performance and increases job satisfaction. For example, employees in the selected brewing firms seem not to be committed to their job because of poor working conditions, poor feedback on goal progress and low remuneration, these made them feel not motivated and want to move out to look for greener pasture. These problems have contributed to the collapse of some of the breweries in the South East region of Nigeria.

Sequel to the above mentioned problem, the study seeks to ascertain the extent to which 
self-efficacy determines employee commitment in selected breweries in South East Nigeria.

\subsection{Objective of the Study}

The main objective of the study is to ascertain the extent of relationship that exists between self-efficacy and employee commitment in selected breweries in South East Nigeria. The study specifically seeks to identify the extent to which self-esteem determines job satisfaction in selected breweries in South East Nigeria.

\subsection{Hypothesis}

There is a significant relationship between self-esteem and job satisfaction in selected breweries in South East Nigeria.

\section{Review of Related Literature}

\subsection{Conceptual Review}

\subsubsection{Self-Efficacy}

Self-efficacy is the level of one's belief in one's own ability to attain goals or complete tasks. Self-efficacy is seen as an outcome of interactions between the environment and other self-adjustment mechanisms, individual capabilities, experience and accomplishments. It is an essential factor for behavioral change and a component of self-control. It is also a vehicle for motive recognition. Self-efficacy is conceptualized as an individual's perception about himself that he can perform any work by utilizing his abilities and capabilities. Bandura (1995) defines self-efficacy as the belief in one's ability in order to perform task in difficult environment. When low self-efficacy is present in an individual, negative feeling about one's abilities and responsibilities for one's own performance can be triggered. A high level of self-efficacy triggers feeling that one is responsible for one's destiny and that one can do what one wants to do. Perceived self-efficacy is seen as people's feelings about their capacities to produce required levels of performance that exercise influence over events that affect their lives. It also determines how individuals perceive, think, motivate themselves and behave in a particular way.

A high level of self-efficacy enhances human fulfillment and individual's well-being in several ways. Individuals with confidence in their capacities approach arduous tasks as challenges to be learnt from, rather than threats to be ignored.

In contrast, individuals who are not sure about their capabilities avoid difficult tasks which they see as personal threats. They seem to have low aspirations and are not committed to the goals they choose to achieve.

As individuals learn, experience and mature into more complex individuals, the development of self-efficacy beliefs continue. Bandura (1997) listed four major factors that contribute to the development of self-efficacy as:

1) Performance accomplishments: Individuals with successful stories of experience can exert high level of self-efficacy. 
2) Vicarious experience: When individuals observe others who are similar to themselves succeed, this can provoke their belief that they can master a similar activity.

3) Verbal persuasion: When feedback is constructive, self-efficacy is enhanced and may aid in overcoming self-doubt.

4) Physiological states: Individuals being able to reduce anxiety in themselves may trigger positive effect on self-efficacy beliefs.

\subsubsection{Self-Esteem}

Self-esteem is simply how you feel about yourself and how you judge your worth. Having a healthy self-esteem means that you are able to feel good about yourself even though you're not perfect. Individual can be aware of his strengths and still acknowledge his weaknesses without judging himself. Many people are too aware of their weaknesses, but ignore their strengths and good qualities. For this reason, it can be helpful to spend some time thinking about all the positive qualities that you take for granted. It might be helpful to make a list of your strengths and weaknesses you would like to improve upon. Apter (1997) defines self-esteem as a complex set of individual's feelings, beliefs and expectations anchored on their dynamic skills in relating with their environment.

Although it is important to practice self-worth, this does not mean that you shouldn't aim to improve some things about yourself or your life. Sometimes it is helpful for one to set goals for things that you would like to achieve, or to change things that you are not happy with. For example, if you do not feel comfortable in some social situations, it might be useful to work on your communication skills and taking more social risks. While it's often very helpful to set meaningful goals, it is also important to maintain a flexible attitude. This means accepting yourself whether or not you achieve your goals. A positive view of one's self is high self-esteem, while negative view of one's self is low self-esteem. Individuals with high level of self-esteem might be provoked to tackle difficult tasks and if successful, this may result in self-confidence. This self-confidence therefore encourages employee commitment in an organization.

Because of the complex nature of jobs, employees are likely to experience work pressures that affect their confidence and self-esteem with respect to performing prescribed tasks, interacting with team members, and coping with workplace politics, all of which lead to low level of satisfaction. Employees are considerably the valuable assets of the organization. When employees are satisfied with their current job and probably committed to their organization, it increases performance.

\subsubsection{Employee Commitment}

Kanter (1986) defines commitment as the willingness of social actors to give their energy and loyalty to social system. Meyer and Allen (1997), defines commitment as a psychological state that characterizes the employee relationship with decision to continue membership in the organisation. It also reflects the extent to which employee's identify with an organization and is committed to its goals. Employee commitment is important because high levels of commitment lead to several favorable organizational outcomes. 
Commitment is the bond employees experience with their organization. Broadly speaking, employees who are committed to their organization generally feel a connection with their organization, feel that they fit in and, feel they understand the goals of the organization. The added value of such employees is that they tend to be more determined in their work, show relatively high productivity and are more proactive in offering their support.

Commitment is a psychological state that binds an individual to the organization. It refers to the likelihood that an individual will stick to the organization, feel psychologically attached to it, whether the job is satisfying or not. It consists of three factors:

1) A great zeal to continue as a member of the workplace

2) An individual's strong zeal to embrace and accept the values and goals of the workplace

3) Availability and readiness to work on behalf of the organization.

Various forms of commitment have been identified as:

1) Affective Commitment: This is an individual's emotional inclination to the workplace.

2) Normative Commitment: This is internalizing and adapting to a set of norms regarding appropriate conduct.

3) Continuance Commitment: This is associated with gains versus losses of working in an organization.

\subsubsection{Job Satisfaction}

Job satisfaction can be defined as an employee's attitude towards the job. The term job satisfactions refer to the attitude and feelings people have about their work. Positive and favorable attitudes towards the job indicate job satisfaction. Negative and unfavorable attitudes towards the job indicate job dissatisfaction (Armstrong, 2006, cited in Aziri, 2011).

Job satisfaction represents a combination of positive or negative feelings that workers have towards their work. Meanwhile, when a worker employed in a business organization, brings with it the needs, desires and experiences which determine expectations that he has dismissed (Aziri, 2011). It is not same as motivation; rather it is concerned with the attitude and internal state of an individual regarding a particular job. It could, for example, be associated with a personal feeling of achievement, and hence, shaped or determined by pay, supervisory style, and age factors. If the existing job fails to provide psychological or physiological need of an individual, satisfaction from the job might be low. More specifically, job satisfaction can be explained as an employee's general attitude towards the job. It is a multidimensional attitude which is made up of the attitude towards pay, promotions, co-workers, supervision, and the work environment and so on. High job satisfaction implies that the employees like the job, whereas, low job satisfaction relates to the disliking of the job by individuals. Job satisfaction is an intangible variable which is expressed through emotional feelings.

Therefore, we can conclude that, job satisfaction is an employee's positive response toward 
the various aspects of job. It helps to improve job performance, and can be determined by the deviation between employee's expectation about job outcome and what the job actually offer.

\subsection{Theoretical Framework}

This study is anchored on two theories, Social Cognitive Theory by Albert Bandura 1977 and Goal-Setting Theory propounded by Edwin Locke \& Gary Latham 1960.

Albert Bandura developed the Social Cognitive Theory based on the concept that learning is affected by cognitive, behavioral, and environmental factors (Bandura, 1991, cited Schwarzer and Wicklund, 1991). In contrast to the traditional psychological theories that emphasized learning through direct experience, Bandura posited that virtually all learning phenomena can occur by observing other people's behavior and consequence of it (Bandura, 1986). According to Bandura's theory, people with high self-efficacy - that is, those who believe they can perform well - are more likely to view difficult tasks as something to be mastered rather than something to be avoided. According to Bandura's description of the human cognitive self-regulation system, self-efficacy beliefs are the most central and pervasive influence on the choices people make, their goals, the amount of effort they apply to a particular task, how long they persevere at a task in the face of failure or difficulty, the amount of stress they experience and the degree to which they are vulnerable to depression. Social cognition constructs (positive attitude) which refers to a person's self-beliefs in his or her ability to perform specific tasks, has been shown to be a reliable predictor of both self-esteem and task performance, and to influence personal goal setting.

This theory is relevant to this study in the sense that Strong self-efficacy beliefs enhance human accomplishment and personal well-being in many ways. People with a strong sense of personal competence in a field approach difficult task in that field as challenges to be mastered rather than as dangers to be avoided; have great intrinsic interest in activities, set challenging goals and maintain a strong commitment to them, heighten their efforts in the face of failure, more easily recover their confidence after failures or setbacks and attribute failure to insufficient effort or deficient knowledge and skills which they believe they are capable of acquiring. High self-efficacy helps create feelings of serenity in approaching difficult tasks and activities.

The Goal-Setting Theory proposed by Locke \& Latham in 1960 emphasized on the fact that clear and specific goals and effective feedback can essentially motivate employees. According to Locke \& Latham (2006), it states that goal setting is essentially linked to task performance. It states that specific and challenging goals along with appropriate feedback contributes to higher and better task performance. The individual employees should set a personal goal whereas the management of the organization should also focus on setting a team goal in order to comprehensively attain both individual growth and organizational growth.

Goal-setting theory has certain eventualities such as: 
1) Self-efficiency: self-efficiency is the individual's self-confidence and faith that he has potential of performing the task. The higher the level of self-confidence, greater will be the efforts put in by the individual when they face challenging tasks. While, lower the level of self-confidence, less will be the efforts put in by the individual or he might even quite while meeting challenges.

2) Goal commitment: Goal commitment in simple words denotes the acceptance of the goal by the individual. The acceptance of the goal is the initial step towards the motivation of the individuals. Rug \& Wallace (2012) commented that if the goal is achievable and realistic then the rate of acceptance is high and with the advent of acceptance, the individual applies the required degree of determination and self-efficacy in order to complete the goal.

This theory is relevant to this study in the sense that personal goal setting enhances effective performance, motivation and self-confidence. When goal are been used, performance are linked to feedback on results, and it creates commitment and acceptance.

\subsection{Empirical Review}

Several authors in the past have studied self-efficacy in various perspectives and made their different findings. Some of them include:

Uzonwanne and Uzonwanne (2014) carried out a study on the relationship between self-esteem and self-efficacy among Bankers in South West Nigeria. Survey research design was adopted and it was revealed that a significant difference exists between self-esteem and self-efficacy.

Ahmed (2012) studied the role of self-esteem and optimism in job satisfaction among teachers of private universities in Bangladesh. Survey research design was used and data analyzed with Pearson Product Moment Correlation. The result showed that self-esteem and optimism significantly correlate with job satisfaction.

In a study by Popoola and Zaid (2015) to investigate self-efficacy, emotional intelligence, information acquisition and utilization of determinants of effective leadership of managers in packaging companies in Nigeria, correlation and hierarchical regression were used to analyze the data. The findings revealed that significant correlation exists among self-efficacy, emotional intelligence, information acquisition, information utilization and effective leadership.

The study on self-efficacy, emotional intelligence, achievement motivation and work-value orientation as predictors of career commitment of bankers was carried out by Ohizu and Okoye (2011). The study areas were Owerri, Okigwe and Orlu Senatorial Districts of Imo State of Nigeria. Correlation was employed for data analysis. The findings showed relationship among the variables.

Jacob and Jolly (2013) studied the impact of self-efficacy on motivation and performance of employees. Significant relationship was found among self-efficacy, motivation and 
performance using standardized data extraction forms.

Akhtar et al (2012) studied self-efficacy and optimism as predictor of organization commitment among bankers in Sargodha. Multiple regression model was used. It was found out that self-efficacy emerged as significant predictor, while the optimism was not significant predictor of organizational commitment.

Yi-Chun and Ya-Sin (2013) carried out a study on self-efficacy and career commitment in Taiwan. Correlational analysis was used. The results showed that self-efficacy negatively moderated the relationship between job content and career commitment.

Judges, Jackson, Shaw and Rich (2007) studied the unique contribution of self-efficacy to work-related performance. The finding which was based on meta-analysis of the relevant literature revealed that the predictive validity of self-efficacy is attenuated in the presence of individual differences though the attenuation does depend on the context.

Dijk (2009) performed a study on self-efficacy and job stress during organizational change. The study used multiple regression analysis. The result revealed that self-efficacy is an important factor to influence the amount of stress among employees.

Niu (2010) identified the link between self-efficacy and career commitment of 1025 employees of food service industry. ANOVA was used for analysis. The finding showed a positive relationship between self-efficacy and career commitment.

\section{Methodology}

The research design adopted for this study is the descriptive survey research design. It is used because of the nature of the study. Survey research design enables the study to observe what happens to the sample subjects without manipulating them. The researcher purposively picked a sample of three (3) brewing firms in South East Nigeria.

The population of the study is made up of employees of three brewing firms in south east Nigeria. The three brewing firms were picked using judgmental sampling technique out of several firms which constitute the food and beverage firms.

Table 1. Population Table

\begin{tabular}{lcc}
\hline Brewing Firms & Locations & Population \\
\hline Guniness Nigeria Plc & Abia & 60 \\
SABMiller Plc & Anambra & 56 \\
Nigeria Breweries & Enugu & 40 \\
Total $\quad 156$ & & \\
\hline
\end{tabular}

Source: Field Survey, 2017. 


\section{Macrothink}

Due to the small size of the population complete enumeration was used for the study.

Data were collected from primary sources. The primary data involves obtaining information directly from the respondent through a structured questionnaire. The questionnaire was made up of section A and B. Section A sought information on personal data of the respondents. Section B consists of information relating to the problem, objectives and research questions. The questionnaire was structured on a five point rating scale ranging from strongly agree to strongly disagree.

The questionnaire developed for this study was subjected to content validity. Content validity is the extent which measuring instrument provides adequate coverage of the topic under study (Onyeizugbe, 2013). The questions in the questionnaire were well structured in line with the objective of the study. The instrument was subjected to expert's evaluation in measurement and management from which necessary corrections were made before the questionnaire was distributed to respondents.

The result obtained after testing the reliability of the instrument using Spearman Brown's Split Half technique was 0.95 . A reliability coefficient that is above 0.7 is regarded as a reliable instrument that is capable of eliciting consistent result and as such this instrument is certified reliable. The result obtained is shown below:

Formula adopted was:

$$
r_{S B}=\frac{2 \mathrm{r}_{\mathrm{hh}}}{1+r_{h h}}
$$

Where

$r_{h h}=$ Pearson correlation of scores in the two half tests.

Applying the formula, we would have:

$$
\begin{gathered}
r_{S B}=\frac{2 \times .857}{1+.857} \\
r_{S B}=\frac{1.714}{1.857} \\
r_{S B}=0.92299 \\
r_{S B}=0.922
\end{gathered}
$$


Pearson's Product Moment Correlation Coefficient was used in analyzing the data which is to explore the extent to which self-esteem relates with job satisfaction in selected brewing firms in South East Nigeria. The level of significance used was $5 \%$ and the confidence interval 95\%.

\section{Data Presentation and Analysis}

\subsection{Data Presentation}

The data presentation and description were guided by the study questions, which were first stated, after which the data collected with regard to each of the questions were analysed. One hundred and fifty-six (156) copies of questionnaire were distributed to the respondents and 108 copies were filled and returned. The study used the 108 copies for the analysis.

Table 2. Demographic Information of Respondents on Gender

\begin{tabular}{llllll}
\hline & & Frequency & Percent & Valid Percent & Cumulative Percent \\
\hline \multirow{3}{*}{ Valid } & Female & 48 & 40.3 & 44.4 & 44.4 \\
\cline { 2 - 6 } & Male & 60 & 50.4 & 55.6 & 100.0 \\
\cline { 2 - 6 } & Total & 108 & 90.8 & 100.0 & \\
\hline Missing & System & 11 & 9.2 & & \\
\hline Total & & 119 & 100.0 & & \\
\hline
\end{tabular}

Source: Field Survey, 2017.

The table 2 above shows that 60 respondents are males (i.e. 50.4\%), while 48 persons were females (i.e. $40.3 \%$ ).

Table 3. Demographic Information of Respondents on Age

\begin{tabular}{llllll}
\hline & & Frequency & Percent & Valid Percent & Cumulative Percent \\
\hline \multirow{4}{*}{ Valid } & $30-35$ & 16 & 13.4 & 14.8 & 14.8 \\
\cline { 2 - 6 } & $36-40$ & 32 & 26.9 & 29.6 & 44.4 \\
\cline { 2 - 6 } & $41-45$ & 21 & 17.6 & 19.4 & 63.9 \\
\cline { 2 - 6 } & 46- Above & 39 & 32.8 & 36.1 & 100.0 \\
\cline { 2 - 6 } & Total & 108 & 90.8 & 100.0 & \\
\hline Missing & System & 11 & 9.2 & & \\
Total & & 119 & 100.0 & &
\end{tabular}

Source: Field Survey, 2017.

From the table 3 above shows the number of participants between the ages of 30 to 35 years of age is 16 (13.4\%), participants between the ages of 36 to 40 years of age is 32 (26.9\%), participants between the ages of 41 to 45 years of age is 21 (17.6\%), While participants 46 years of age and above is 39 (32.8\%). 
Table 4. Demographic Information of Respondents on Marital Status

\begin{tabular}{llllll}
\hline & & Frequency & Percent & Valid Percent & Cumulative Percent \\
\hline \multirow{4}{*}{ Valid } & Single & 37 & 31.1 & 34.3 & 34.3 \\
\cline { 2 - 6 } & Married & 55 & 46.2 & 50.9 & 85.2 \\
\cline { 2 - 6 } & Others & 16 & 13.4 & 14.8 & 100.0 \\
\cline { 2 - 6 } & Total & 108 & 90.8 & 100.0 & \\
\hline Missing & System & 11 & 9.2 & & \\
\hline Total & & 119 & 100.0 & &
\end{tabular}

Source: Field Survey 2017

From the table 4 above, the number of participants who are single is 37 (31.1\%), the table also shows that $55(46.2 \%)$ of the participants are married while $16(13.4 \%)$ where not willing to disclose their marital status.

Table 5. Demographic Information of Respondents on Work Experience

\begin{tabular}{llllll}
\hline & \multicolumn{5}{l}{ FrequencyPercentValid PercentCumulative Percent } \\
\hline \multirow{4}{*}{ Valid } & $0-5$ & 16 & 13.4 & 14.8 & 14.8 \\
\cline { 2 - 6 } & $6-10$ & 31 & 26.1 & 28.7 & 43.5 \\
\cline { 2 - 6 } & $11-15$ & 16 & 13.4 & 14.8 & 58.3 \\
\cline { 2 - 6 } & $16-$ Above45 & 37.8 & 41.7 & 100.0 \\
\cline { 2 - 6 } & Total & 108 & 90.8 & 100.0 & \\
\hline MissingSystem & 11 & 9.2 & & \\
\hline \multicolumn{7}{l}{ Total } & 119 & 100.0 & \\
\hline
\end{tabular}

Source: Field Survey, 2017.

From the table 5 above, Years of experience showed that 16 respondents (i.e. 13.4\%) have between 0 to 5 years working experience, 31 respondents (i.e. 26.1\%) have 6 to 10 years working experience, 16 respondents (i.e. 13.4\%) have 11 to 15 years working experience while 45 respondents (i.e. 37.8\%) have 16 years working experience and above. This is an indication that over $40 \%$ of respondents have stayed long on this particular job.

Table 6. Demographic Information of Respondents on Category of Staff

\begin{tabular}{|c|c|c|c|c|c|c|}
\hline & & & Frequency & Percent & $\begin{array}{l}\text { Valid } \\
\text { Percent }\end{array}$ & $\begin{array}{l}\text { Cumulative } \\
\text { Percent }\end{array}$ \\
\hline Top & level & (Line) & 24 & 20.2 & 22.2 & 22.2 \\
\hline
\end{tabular}




\begin{tabular}{llllll}
\hline \multicolumn{1}{c}{ Managers } & & & & \\
\hline Valid & Casual staff & 84 & 70.6 & 77.8 & 100.0 \\
\hline & Total & 108 & 90.8 & 100.0 & \\
\hline Missing & System & 11 & 9.2 & & \\
\hline Total & & 119 & 100.0 & & \\
\hline
\end{tabular}

Source: Field Survey, 2017.

The table 6 above shows that 84 respondents (i.e. 70.6\%) are casual staff while only 24 respondents (20.2\%) are line managers.

\subsection{Data Analysis}

Table 7. Self-esteem

\begin{tabular}{|l|l|l|l|l|l|l|l|l|}
\hline Items & SA & A & UD & D & SD & N & Sum & Mean \\
\hline $\begin{array}{l}\text { I can remain calm when facing } \\
\text { difficulties because I rely on my } \\
\text { coping abilities }\end{array}$ & 63 & 3 & 15 & 9 & 18 & 108 & 408 & 3.78 \\
\hline $\begin{array}{l}\text { No matter what comes my way, I'm } \\
\text { usually able to handle it }\end{array}$ & 54 & 7 & 17 & 15 & 15 & 108 & 394 & 3.65 \\
\hline $\begin{array}{l}\text { On a whole, I am satisfied with } \\
\text { myself }\end{array}$ & 50 & 7 & 17 & 17 & 17 & 108 & 380 & 3.52 \\
\hline $\begin{array}{l}\text { Thanks to my resourcefulness, I know } \\
\text { to handle unforeseen situations }\end{array}$ & 63 & 3 & 3 & 17 & 22 & 108 & 392 & 3.63 \\
\hline I take a positive view of myself. & 71 & 7 & 4 & 22 & 4 & 108 & 443 & 4.10 \\
\hline Valid N (listwise) & & & & & & 108 & & \\
\hline
\end{tabular}

Source: Field Survey, 2017.

Table 7 above shows the responses of the respondent on self-esteem.

Table 8. Job Satisfaction

Items

SAA UDD SDN SumMean

I would be willing to make a greater effort than expected in order97 $3 \quad 3 \quad 50$

to contribute to the success of my organisation.

1085164.78

This firm means a lot to me personally.

$12906 \quad 000 \quad 1084384.06$

At the current time staying with the organisation is more of a64 319715

question of need than a desire or will

1084183.87

I feel my personal values fit with those of the organisation

5751813151084003.70

I stay with this organisation because I feel that I would not easily53 5211712

find an opportunity with another firm. 
Source: Field Survey, 2017.

Table 8 above shows the responses of the respondent on job satisfaction.

\subsection{Test of Hypothesis}

$\mathbf{H}_{\mathbf{1}}$ : There is a significant positive relationship between self-esteem and job satisfaction of employees in selected brewing firms in South East Nigeria.

Table 9. Correlations Matrix

\begin{tabular}{llll}
\hline & & SE & JS \\
\hline SE & Pearson Correlation & 1 & $.779^{* *}$ \\
\cline { 2 - 4 } & Sig. (2-tailed) & 108 & .000 \\
\cline { 2 - 4 } & $\mathrm{N}$ & $.779^{* *}$ & 108 \\
\hline \multirow{2}{*}{ JS } & Pearson Correlation & .000 & 1 \\
\cline { 2 - 4 } & Sig. (2-tailed) & 108 & 108 \\
\cline { 2 - 4 } & $\mathrm{N}$ & & \\
\hline
\end{tabular}

**. Correlation is significant at the 0.01 level (2-tailed).

Source: Field Survey, 2017.

\section{Discussion of Findings, Summary of Findings, Conclusion and Recommendations}

\subsection{Discussion of Findings}

Findings of the study have shown that there is a strong positive relationship between self-efficacy and job satisfaction in the selected brewing firms in South East Nigeria. Ahmed (2012) posits that self-esteem and optimism is significantly correlated with job satisfaction. The results mean that teachers who had high self-esteem had high job satisfaction. This means that increase or decrease of self-esteem significantly relates to increase or decrease of job satisfaction. Self-esteem and job satisfaction is obviously important for factors such as; self-confident, self-concept, performance and working with cooperation. However, these findings signify that the higher the self-esteem, the higher the job satisfaction and vice-versa which show a relationship between the two variables which seem to increase employees coping worth.

The table above shows a Pearson Product-Moment Correlation run to determine the relationship that exists between self-esteem and job satisfaction of employees. The result shows that $\mathrm{p}$-value $(0.000)<0.01$ (at a 2 -tailed test). This means that the result is statistically significant at a $5 \%$ confidence level. The value 0.779 shows that there is a strong positive relationship between self-esteem and job satisfaction of employees in the brewing firm in South East Nigeria. This explains that a high self-esteem brings a proportionate job satisfaction generally. 


\subsection{Conclusion}

It can be concluded from the data analysis and hypothesis tested that there is a highly positive relationship between self-esteem and job satisfaction. In order to survive in the modern competitive market employees have to be effective so as to meet the requirements of their organizational goals. Employees who daily accomplish their duties represent an important factor for self-efficacy. Their beliefs of self-efficacy may enhance their willingness to work and contribute to their readiness to bring an extra effort on behalf of their organization. All these have positive impact on the organizational performance. It is worth noting that the final goal of both self-esteem and job satisfaction research is to help employees in the brewing firms across South East Nigeria to function better.

\subsection{Recommendations}

Base on the findings and conclusion, the following were recommended:

Employees should ensure that they develop positive self-esteem at work so as to feel better about themselves, enjoy their work, put more time and effort on difficult tasks and feel less anxious at work.

Employees should ensure that they develop self-confidence which heightens efficacy and increases job satisfaction.

Feedback on goal progress should be communicated to the employees so as to sustain motivation and promotes performance.

\section{References}

Aborisade, R., \& Obioha, E. E. (2009). The Role of Motivation in Enhancing Job Commitment in Nigeria Industries: A Case Study of Energy Foods Company Limited, Ibadan. Journal of Social Sciences, 19(2), 149-154.

Ahmed, M. A. (2012). The Role of Self-esteem and Optimism in Job Satisfaction among Teachers of Private Universities in Bangladesh. Asian Business Review, 1(1), 114-120.

Akhtar, S., Ghayas, S., \& Adil, A. (2012). Self- Efficacy and Optimism as Predicators of Organizational Commitment among Bank Employees. International Journal of Research Studies in Psychology, 2, 33-42,

Apter, T. (1997). The Confident Child. New York: W.W. Norton company, Inc.

Aziri, B. (2011). Job Satisfaction: A Literature Review. Management Research and Practice, 3(4), 77-78.

Bandura, A. (1977). Social Learning Theory. Englewood Cliffs, NJ: Prentice Hall.

Bandura, A. (1986). Social Foundations of Thought and Action. Upper Saddle River, NJ: ed. Jessey-Bass, San Francisco, 373-421. 
Bandura, A. (1995). Exercise of Personal and Collective Efficacy in Changing Societies. New York: Cambridge University Press, New York, NY.

Baum (2007). An Analysis of the Food and Beverage Sector. Retrieved from http://dspace.nwu.ac.za/bitstream/handle/10394/9541/Viljoen_AH_chapter_2.pdf

Brockner, T. (1988). Self-Esteem at Work: Theory, Research and Practice. Lexington, MA: Lexington Books.

Dijk, M. V. (2009) Employee Self-Efficacy and Job Stress During Organizational Change. University of Twente.1-17.

Dixit V., \& Bhati, M. (2012) A study about Employee Commitment and Its Impact on Sustained Productivity in Indian Auto-component Industry. European Journal of Business and Social Sciences, 1(6), 34-51.

Ghazali, S. S., Shah, I. A., Zaidi, S. A., \& Tahir, M. H. (2007). Job Satisfaction Doctors Working at Teaching Hospital of Bahawalpur, Pakistan. Journal of Ayub Medical College Abbottabad, 19(3), 42-45. Retrieved from http://www.ayubmed.edu.pk/JAMC/PAST/19-3/11\%20Ghazali.pdf

Jacob Cherian \& Jacob Jolly (2013) Impact of Self-Efficacy on Motivation and Performance of Employees. International Journal of Business and Management, 8(14), 80-88

Judge, T. A., Jackson, C. L., Shaw, J. C., Scott, B. A., \& Rich, B. L. (2007). Self-Efficacy and Work-Related Performance: The Integral Role of Individual Differences. Journal of Applied Psychology, 92(1), 107-127.

Lent, R. W., Brown, S. D., \& Hackett, G. (1994). Toward a Unifying Social Cognitive Theory of Career and Academic Interest, Choice, and Performance. Journal of Vocational Behavior. 45, 79-122.

Locke, E. A., \& Latham, G. P. (1990). A Theory of Goal Setting and Task Performance. Upper Saddle River, NJ: Prentice Hall.

Locke, E. A., \& Latham, G. P. (2006). New Directions in Goal-Setting Theory. Current Directions in Psychological Science, 15(5), 265-268.

Lopez, E. M. (1982). A Test of Self-Consistency Theory of Job Performance-Job Satisfaction Relationship. Academy of Management Journal, 25(2), 335-348.

Marczyk, G.R, Dematteo, D., \& Festinger, D. (2005) Essentials of Research Design and Methodology. John Wiley and Sons, Inc. Hoboken, New Jersey.

Meyer J. P., \& Allen, L. (1999). Commitment in the Workplace. Theory, Research and Application.

Niu, H. J. (2010) Investigating the Effect of Self-Efficacy on Food Service Industry 


\section{Macrothink}

Employee Career Commitment. International Journal of Hospitality Management, 29, 743-750.

Ohizu, E. C., \& Okoye O. E. (2014) Self-Efficacy Emotional Intelligence, Achievement Motivation and Work-Value Orientation as Predicators of Career Commitment. IOSR Journal of Business and Management, 16(11), 55-62.

Onyeizugbe, C. U. (2013). Practical Guide to Research Methodology in Management. Onitsha: Good Success Press.

Popoola, S. O., \& Zaid, Yetunde A. (2015) Effective Leadership, Self-efficacy, Emotional Intelligence, Human Acquisition and Utilization of Managers in Packaging Companies in Nigeria. Information and Knowledge Management, 5(1).

Ramachaudran, V. S. (1998) Encyclopedia of Human Behaviour. New York : Academic Press.

Schank (2012), Self-Esteem. Retrived from http://kb.edu.hku.hk/self-esteem.html.

Schwarzer, R., \& Wicklund, R. A. (1991) Anxiety and Self-focused Attention. New york : Harwood Academic.

Uzonwanne, F. C., Uzonwanne, Godfrey C. (2014) Prevalance of Self-Efficacy and Self-Esteem among Banker in Selected Southwest States in Nigeria. Journal of Humanities and Social Science, 19(8), 110-119.

Yi-Chun, L., \& Ya-Sin, L. (2013) The Moderating Effect of Self-Efficacy on the Relationship Between Job Content Plateau and Career Commitment. Journal of Management, 3(1), 1-15.

\section{Copyrights}

Copyright for this article is retained by the author(s), with first publication rights granted to the journal.

This is an open-access article distributed under the terms and conditions of the Creative Commons Attribution license (http://creativecommons.org/licenses/by/4.0/) 